\title{
Article
}

\section{Treatment of Erythroid Precursor Cells from $\beta$-Thalassemia Patients with Cinchona Alkaloids: Induction of Fetal Hemoglobin Production}

\author{
Cristina Zuccato ${ }^{1}{ }^{\mathbb{D}}$, Lucia Carmela Cosenza ${ }^{1}$, Matteo Zurlo ${ }^{1}{ }^{\mathbb{D}}$, Ilaria Lampronti ${ }^{1,2}$, Monica Borgatti ${ }^{1,2} \mathbb{D}$, \\ Chiara Scapoli ${ }^{3}$, Roberto Gambari ${ }^{1,2,4, *}$ and Alessia Finotti ${ }^{1,2,4, *(D)}$
}

1 Section of Biochemistry and Molecular Biology, Department of Life Sciences and Biotechnology, University of Ferrara, 44121 Ferrara, Italy; cristina.zuccato@unife.it (C.Z.); luciacarmela.cosenza@unife.it (L.C.C.); matteo.zurlo@unife.it (M.Z.); ilaria.lampronti@unife.it (I.L.); monica.borgatti@unife.it (M.B.)

2 Research Laboratory "Elio Zago" on the Pharmacologic and Pharmacogenomic Therapy of Thalassemia (Thal-LAB), University of Ferrara, 44121 Ferrara, Italy

3 Section of Biology and Evolution, Department of Life Sciences and Biotechnology, University of Ferrara, 44121 Ferrara, Italy; chiara.scapoli@unife.it

4 Interuniversity Consortium for Biotechnology (C.I.B.), 34148 Trieste, Italy

* Correspondence: gam@unife.it (R.G.); alessia.finotti@unife.it (A.F.); Tel.: +39-0532-974443 (R.G.); +39-0532-974510 (A.F.); Fax: +39-0532-974500 (R.G. \& A.F.)

check for updates

Citation: Zuccato, C.; Cosenza, L.C.; Zurlo, M.; Lampronti, I.; Borgatti, M.; Scapoli, C.; Gambari, R.; Finotti, A. Treatment of Erythroid Precursor Cells from $\beta$-Thalassemia Patients with Cinchona Alkaloids: Induction of Fetal Hemoglobin Production. Int. J. Mol. Sci. 2021, 22, 13433. https:// doi.org/10.3390/ijms222413433

Academic Editor: Ivano Condò

Received: 4 October 2021

Accepted: 9 December 2021

Published: 14 December 2021

Publisher's Note: MDPI stays neutral with regard to jurisdictional claims in published maps and institutional affiliations.

Copyright: (c) 2021 by the authors. Licensee MDPI, Basel, Switzerland. This article is an open access article distributed under the terms and conditions of the Creative Commons Attribution (CC BY) license (https:// creativecommons.org/licenses/by/ $4.0 /)$.

\begin{abstract}
: $\beta$-thalassemias are among the most common inherited hemoglobinopathies worldwide and are the result of autosomal mutations in the gene encoding $\beta$-globin, causing an absence or low-level production of adult hemoglobin $(\mathrm{HbA})$. Induction of fetal hemoglobin $(\mathrm{HbF})$ is considered to be of key importance for the development of therapeutic protocols for $\beta$-thalassemia and novel $\mathrm{HbF}$ inducers need to be proposed for pre-clinical development. The main purpose on this study was to analyze Cinchona alkaloids (cinchonidine, quinidine and cinchonine) as natural HbF-inducing agents in human erythroid cells. The analytical methods employed were Reverse Transcription quantitative real-time PCR (RT-qPCR) (for quantification of $\gamma$-globin mRNA) and High Performance Liquid Chromatography (HPLC) (for analysis of the hemoglobin pattern). After an initial analysis using the K562 cell line as an experimental model system, showing induction of hemoglobin and $\gamma$-globin mRNA, we verified whether the two more active compounds, cinchonidine and quinidine, were able to induce $\mathrm{HbF}$ in erythroid progenitor cells isolated from $\beta$-thalassemia patients. The data obtained demonstrate that cinchonidine and quinidine are potent inducers of $\gamma$-globin mRNA and $\mathrm{HbF}$ in erythroid progenitor cells isolated from nine $\beta$-thalassemia patients. In addition, both compounds were found to synergize with the $\mathrm{HbF}$ inducer sirolimus for maximal production of $\mathrm{HbF}$. The data obtained strongly indicate that these compounds deserve consideration in the development of pre-clinical approaches for therapeutic protocols of $\beta$-thalassemia.
\end{abstract}

Keywords: $\beta$-thalassemia; fetal hemoglobin; $\gamma$-globin; $\mathrm{HbF}$ induction; K562 cells; Cinchona alkaloids; cinchonidine; quinidine; cinchonine; combined treatments

\section{Introduction}

$\beta$-thalassemias are among the most common inherited hemoglobinopathies worldwide, and are the result of more than 300 autosomal mutations of the gene encoding $\beta$-globin, causing an absence or low-level synthesis of this protein (and consequently of adult hemoglobin, $\mathrm{HbA}$ ) in erythropoietic cells [1-5]. The phenotypes range widely from asymptomatic ( $\beta$-thalassemia trait or carrier) to clinically relevant anemia, which is categorized as transfusion-dependent $\beta$-thalassemia (TDT, including thalassemia major) and non-transfusion-dependent $\beta$-thalassemia (NTDT, thalassemia intermedia) [1]. 
In the therapy of $\beta$-thalassemia, the induction of fetal hemoglobin $(\mathrm{HbF})$ is considered to be of key importance for several concurrent reasons. In rare forms of $\beta^{0}$-thalassemia, particularly those with large deletions responsible for $\delta \beta^{0}$-thalassemia or hereditary persistence of fetal hemoglobin (HPFH), high $\gamma$-globin chain production results in high levels of $\mathrm{HbF}$, which is associated with a relatively benign phenotype [6-9]. More-recent clinical studies have disclosed that the naturally higher production of $\mathrm{HbF}$ improves the clinical course in a variety of patients with $\beta$-thalassemia [10-14]. Furthermore, approaches using genome editing are available in a form that is finalized to the induction of $\mathrm{HbF}$ following the elimination of genomic sequences encoding for $\gamma$-globin gene transcriptional repressors or genomic sequences targeted by these regulatory factors [15-19]. In this context, clinical trials are ongoing, such as NCT03655678 (A Safety and Efficacy Study Evaluating CTX001 in Subjects with Transfusion-Dependent $\beta$-Thalassemia), based on the use of autologous CRISPR-Cas9 Modified CD34 ${ }^{+}$Human Hematopoietic Stem and Progenitor Cells (hHSPCs) using CTX001 [20].

While some positive results have been described based on $\mathrm{HbF}$ induction by gene editing, the safety of this approach is still to be determined and, even in the case that its safety is demonstrated, the expected costs of this therapeutic approach would still be very high [21-23].

Accordingly, the validation of clinical relevance of already known $\mathrm{HbF}$ inducers and the characterization of novel $\mathrm{HbF}$ inducers are still projects of great interest [24-27].

In this context, a recent paper was published on the effects of Cinchona alkaloids (cinchonidine and quinidine) as natural fetal hemoglobin-inducing agents, using the human erythroleukemia K562 cell line as in vitro experimental model system [28]. In this study, Cinchona alkaloids showed dose-dependent induction of erythroid differentiation, increased production of $\mathrm{HbF}$ and high contents of $\gamma$-globin mRNA. Despite the fact that this study was based only on the use of K562 cells as a model system, it demonstrated that Cinchona alkaloids should be considered for the development of therapeutic protocols for $\beta$-thalassemia [28]. In addition, it should be underlined that molecules belonging to this family have been extensively used in therapy for other indications than $\beta$-thalassemia and, therefore, might be considered as "repurposed drugs" with a facilitated strategy to reach technology transfer [29-34]. For instance, quinine, quinidine, cinchonidine and cinchonine alkaloids had a powerful bioimpact as anti-malarial drugs [29-31]. Quinidine is also used to treat cardiac arrhythmias because it inhibits fibrillation [32-34].

Three are the main objectives of our study: (a) to confirm the data already published on the effects of Cinchona alkaloids (cinchonidine, quinidine and cinchonine) on K562 erythroleukemia cells; (b) to verify whether these molecules might potentiate the activity of other $\mathrm{HbF}$ inducers; (c) to verify whether the more promising Cinchona alkaloids tested induce $\mathrm{HbF}$ in erythroid progenitor cells isolated from $\beta$-thalassemia patients.

In terms of combined treatments, we decided to employ sirolimus (SIR, rapamycin) [35] in the co-treatment experiments for the following reasons: (a) sirolimus increases $\mathrm{HbF}$ in cultures from $\beta$-thalassemia patients with different basal HbF levels [36-39]; (b) sirolimus increases the overall $\mathrm{Hb}$ content per cell [37]; (c) sirolimus selectively induces $\gamma$-globin mRNA accumulation, with only minor effects on $\beta$-globin and $\alpha$-globin mRNAs [36,37]; (d) sirolimus was found to induce $\mathrm{HbF}$ in vivo in mouse model systems [40-42]; and, more importantly, (e) sirolimus was able to increase $\mathrm{HbF}$ in sickle-cell disease (SCD) patients $[43,44]$. For these reasons, sirolimus obtained the Orphan Drug Designation by the European Medicinal Agency (EMA, Europe) and by the Food and Drug Administration (FDA, USA) for both $\beta$-thalassemia and SCD. Of relevance for this study, two ongoing clinical trials are based on sirolimus: NCT03877809 (A Personalized Medicine Approach for $\beta$-thalassemia Transfusion Dependent Patients: Testing sirolimus in a First Pilot Clinical Trial) and NCT04247750 (Treatment of $\beta$-thalassemia Patients with Rapamycin: From Pre-clinical Research to a Clinical Trial) [45]. Finally, it should be noted that sirolimus is a well-known drug, since it is employed for other therapeutic indications, such as kidney transplantation [46,47], cardiac [48] and liver [49] transplantation, lupus erythematosus 
(SLE) [50], lymphangioleiomyomatosis (LAM) [51], tuberous sclerosis complex [52] and different types of cancers [53-55].

\section{Results}

2.1. Cinchonidine, Quinidine and Cinchonine Induce Differentiation of K562 Erythroleukemia Cells

Figure 1 shows that cinchonidine (CincD), quinidine (QuinD) and cinchonine (CincN) are all able to induce erythroid differentiation of human K562 cells in a concentrationdependent fashion. Determinations were performed after 5, 6 and 7 days of differentiation induction.

A<smiles>C=CC1C2CCN1C(Cc1ccnc3ccccc13)C2</smiles>

C<smiles>C=CC1CC2CC(C(O)c3ccnc4ccc(OC)cc34)N1C2</smiles>

$E$<smiles>C=CC1CC2CCN1CC2C(O)c1ccnc2ccccc12</smiles>

Cinchonine

(CincN)
$\mathrm{B}$

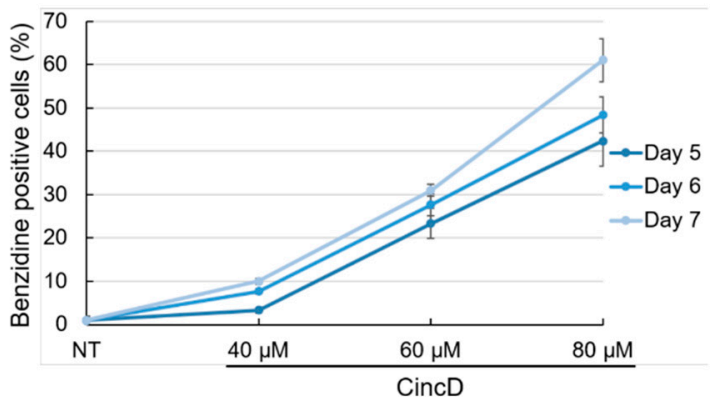

$\mathrm{D}$

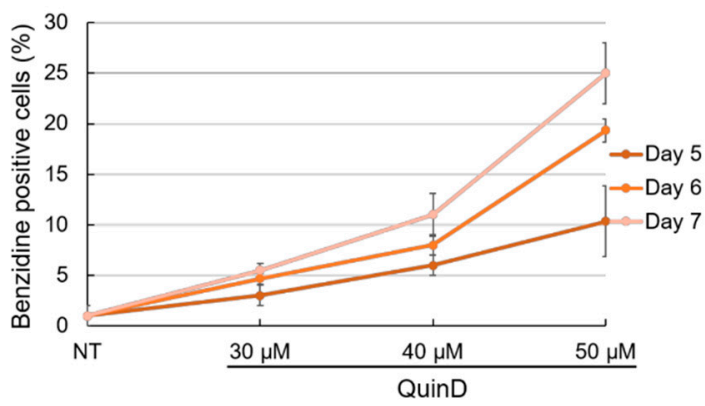

$\mathrm{F}$

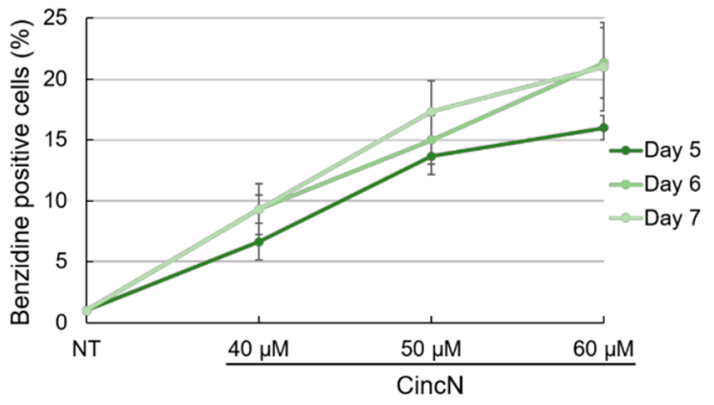

Figure 1. Effects of cinchonidine, quinidine and cinchonine on erythroid differentiation of K562 cells. $(\mathbf{A}, \mathbf{C}, \mathbf{E})$ Structure of cinchonidine (CincD) $(\mathbf{A})$, quinidine (QuinD) $(\mathbf{C})$ and cinchonine $(\mathrm{CincN})(\mathbf{E})$. $(B, D, F)$ Effects on erythroid differentiation of K562 cells. K562 cells were cultured in the presence of the indicated concentrations of cinchonidine (B), quinidine (D) and cinchonine (F) and analysis of the proportion of benzidine-positive hemoglobin-containing cells was performed after 5, 6 and 7 days of cell culture. The data represent the average \pm S.E.M. $(n=3)$. 
After this induction period, cells were stained with benzidine in order to identify the hemoglobin-containing cells [26,36-38]. These data confirm the already-reported effects of these Cinchona alkaloids on the K562 cell system [28]. The induction of K562 differentiation was found to be associated, as expected, with the inhibition of cell proliferation, as reported in the K562 cell system for several other HbF inducers, such as hydroxyurea, mithramycin, rapamycin, cisplatin analogues and trimethylangelicin [25-27,37,56-59]. This effect of cinchonidine, quinidine and cinchonine on K562 cell proliferation is presented and comparatively analyzed in Supplementary Figures S1 and S2. The induction of K562 erythroid differentiation by the studied Cinchona alkaloids was similar (with respect to the extent of the induced proportion of benzidine-positive cells) to that of sirolimus (rapamycin), despite the fact that the effects of sirolimus were appreciable at 100-200 nM (Supplementary Figure S3). These differences among putative erythroid inducers were fully expected [60]. For example, butyrates are active at $\mathrm{mM}$ concentrations [61].

\subsection{Cinchonidine, Quinidine and Cinchonine Potentiate Sirolimus-Induced Differentiation of K562 Erythroleukemia Cells}

In order to verify possible combined effects of Cinchona alkaloids and sirolimus, we treated K562 cells simultaneously with different concentrations of these molecules. The obtained results of the treatment, reported in Figure 2, show that CincD, QuinD and CincN were able to further increase the erythroid differentiation activity of sirolimus, when this $\mathrm{HbF}$ inducer was used at $100 \mathrm{nM}$ (Figure 2, panels A, C and E) and $200 \mathrm{nM}$ (Figure 2, panels B, D and F).

In this experiment, K562 cells were cultured with increasing concentrations of cinchonidine, quinidine and cinchonine in the presence of $100 \mathrm{nM}$ and $200 \mathrm{nM}$ sirolimus, as indicated. The proportion of benzidine-positive K562 cells was determined after 5, 6 and 7 days of treatment. The data presented in Figure $2 \mathrm{G}$ are related to the use of suboptimal concentrations of CincD, QuinD and CincN $(60,40$ and $50 \mu \mathrm{M}$, respectively) in the presence of 100 and $200 \mathrm{nM}$ sirolimus. When the inducers (either sirolimus, or cinchonidine, quinidine and cinchonine) were used alone, the proportion of benzidine-positive hemoglobin-containing K562 cells was about $10-30 \%$. On the contrary, when the inducers were used in combination, the proportion of benzidine-positive hemoglobin-containing K562 cells was always found to exceed 50\% (the maximum level was reached using cinchonidine in combination with $200 \mathrm{nM}$ sirolimus). The increased \% of benzidine-positive cells compared with single administrations was always found to be statistically highly significant $(p<0.001)$. Untreated K562 displayed a proportion of benzidine-positive cells which never exceeded $2-5 \%$ (see, for instance, the microphotographs presented in the left part of Figure 3).

Figure 3 shows a representative microscopic analysis of the benzidine assays performed under some of the different experimental conditions described in Figure 2. The data give clear evidence that, in addition to the already reported increase in the proportion of benzidine-positive cells, and additional feature of combined treatments was evident, i.e., that all the benzidine-positive cells were brightly stained with benzidine-hydrogen peroxide solution (black arrowheads).

On the contrary, the presence of slightly stained benzidine-positive cells was clearly appreciable in singularly treated $\mathrm{K} 562$ cells (white arrowheads). While the representative data shown in Figure 3 were obtained using CincD plus SIR combination, the data obtained using QuinD/SIR and CincN/SIR combinations were found to be very similar (as shown in Supplementary Figure S4). Although this assay was not quantitative, the results obtained sustain the concept that the combined treatments lead to the highest levels of increase in the proportion of brightly stained benzidine-positive K562 cells. In order to verify this hypothesis using a more quantitative assay, RT-qPCR was performed on isolated RNA. 
A

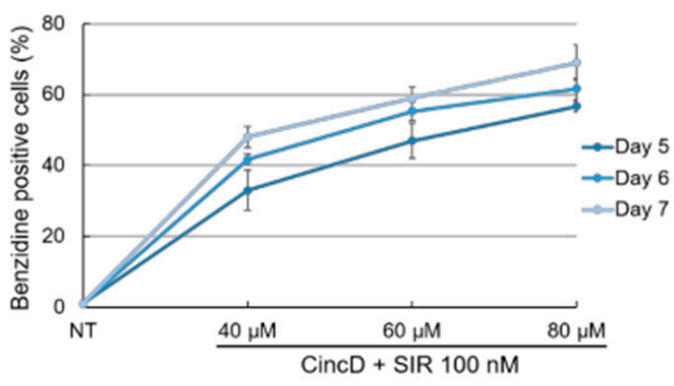

C

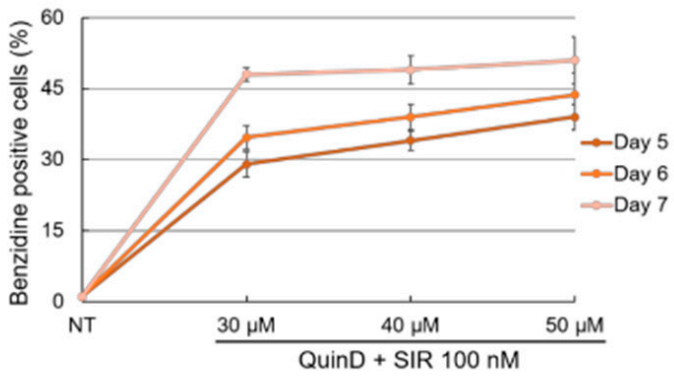

E

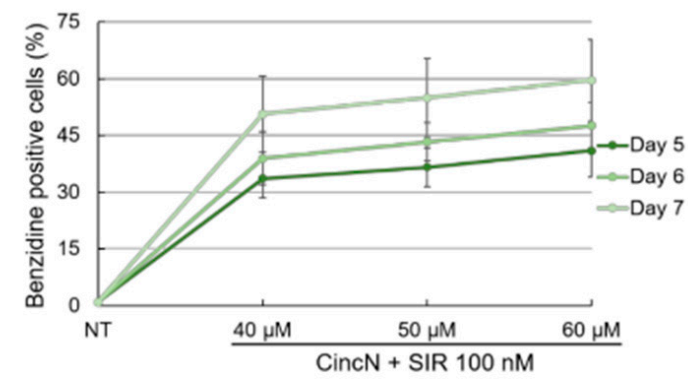

B

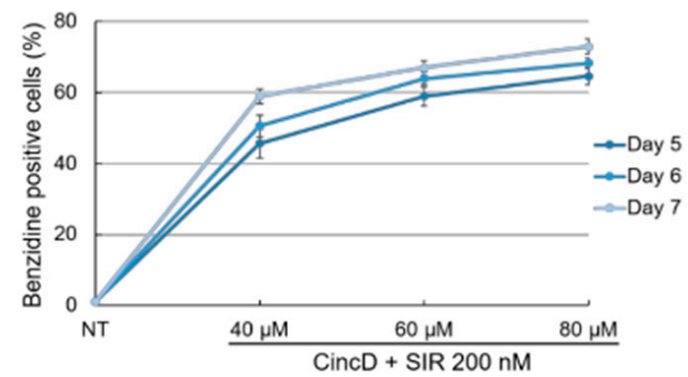

D

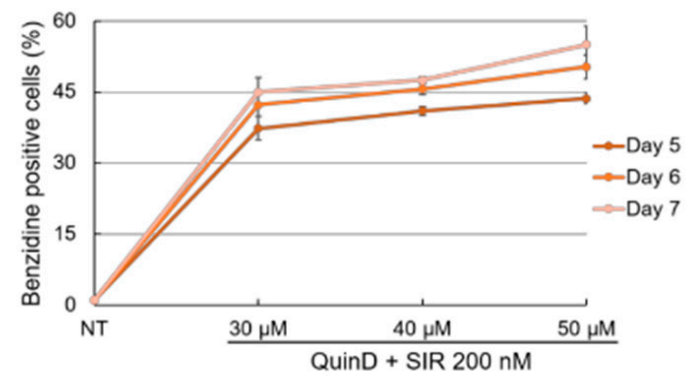

F

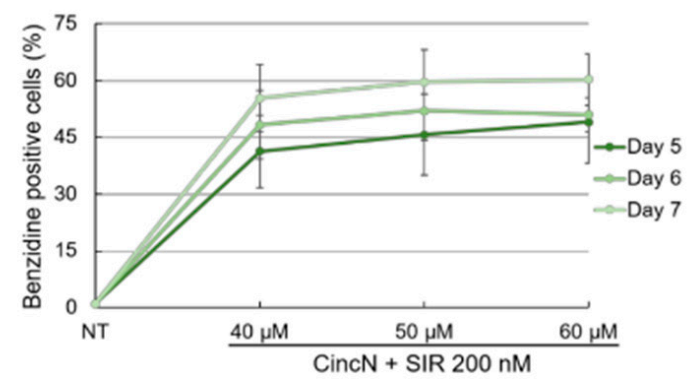

\section{G}

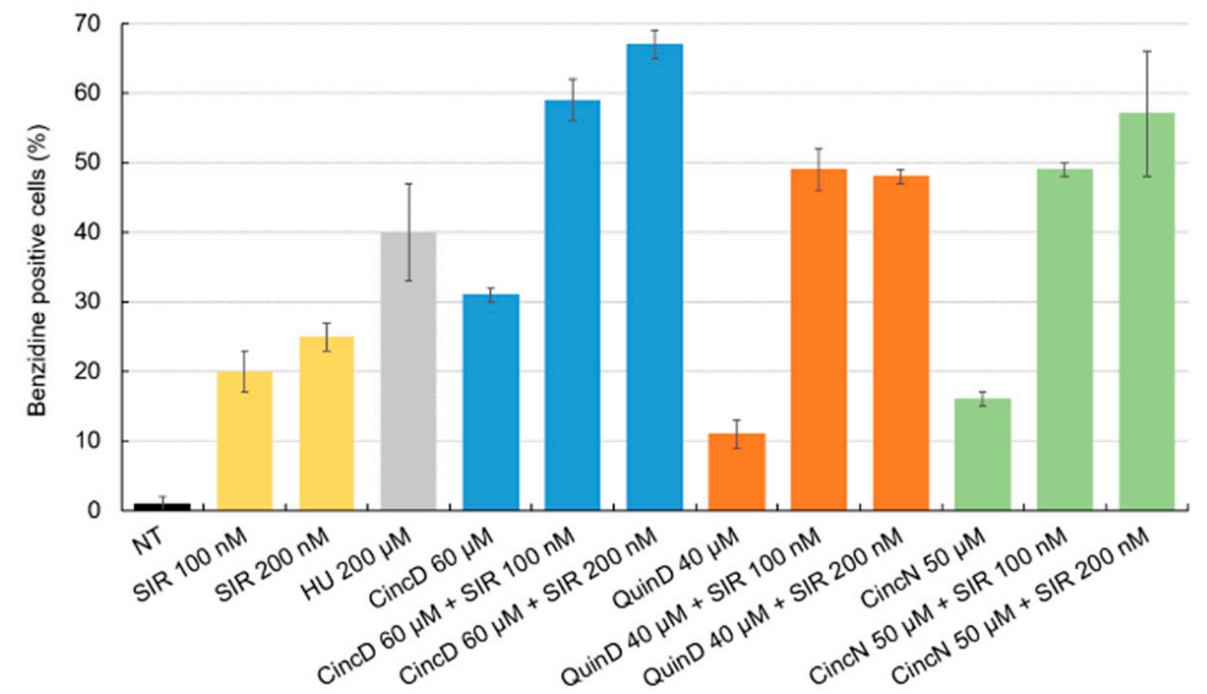

Figure 2. Effects of cinchonidine, quinidine and cinchonine on K562 erythroid differentiation induced by sirolimus. K562 cells were cultured with increasing concentrations of $\operatorname{CincD}(\mathbf{A}, \mathbf{B})$, QuinD (C,D) and CincN (E,F) in the presence of $100 \mathrm{nM}$ (A,C,E) and $200 \mathrm{nM}(\mathbf{B}, \mathbf{D}, \mathbf{F})$ sirolimus (SIR). The proportion of benzidine-positive K562 cells was determined after 5, 6 and 7 days of treatment, as indicated. $(\mathrm{G})$ Comparative analysis of the data obtained at day 7 of treatment. The data represent the average \pm S.E.M. $(n=3)$. 

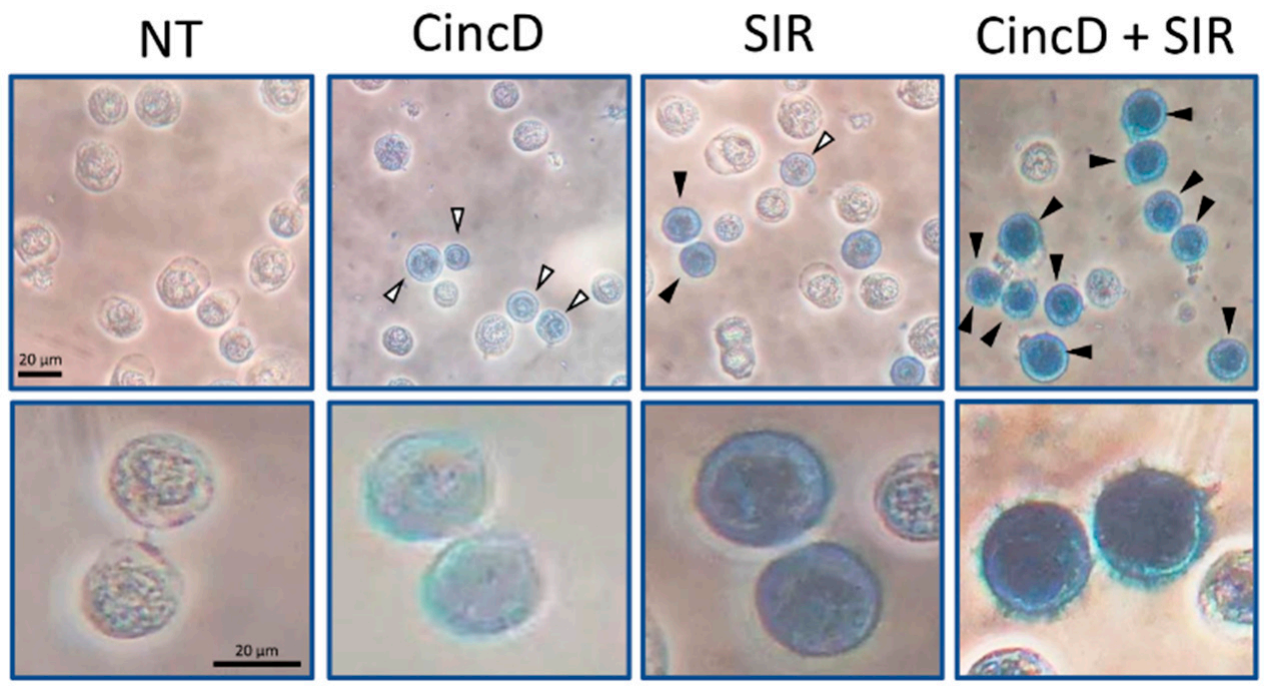

Figure 3. Benzidine-positive cells in untreated K562 cell cultures (NT) or in K562 cell cultures treated with CincD, SIR and CincD + SIR, as indicated. White arrowheads = slightly benzidine-stained cells; black arrowheads $=$ brightly benzidine-stained cells. Magnitude: $20 \times$ (upper panels) and $40 \times$ (lower panels). Scale bar, $20 \mu \mathrm{m}$.

2.3. The Effects of Cinchonidine, Quinidine and Cinchonine on K562 Erythroid Differentiation Are Associated with a Modulation of Expression of $\alpha$-Globin and $\gamma$-Globin Genes

Figure 4 shows that the erythroid differentiation induced by cinchonidine, quinidine and cinchonine was associated with an increase in the production of $\alpha$-globin (Figure 4A,C,E) and $\gamma$-globin mRNAs (Figure 4B,D,F). The analysis of the expression of $\alpha$-globin and $\gamma$-globin mRNAs was performed by RT-qPCR.

Interestingly, when used singularly, the increases in the production of both mRNAs induced by CincD (Figure 4A,B), QuinD (Figure 4C,D), and CincN (Figure 4E,F) were found to be similar to those found when $100 \mathrm{nM}$ and $200 \mathrm{nM}$ sirolimus was employed $(p>0.05)$. In addition, the increased levels of $\gamma$-globin mRNAs were similar to those originally described by Iftikhar et al. [28]. On the contrary, when cinchonidine, quinidine and cinchonine were used in combination with $100 \mathrm{nM}$ and $200 \mathrm{nM}$ sirolimus, a sharp increase in the content of $\alpha$-globin mRNA $(p<0.01)$ and a less extensive but still significant $(p<0.05)$ increase in $\gamma$-globin mRNAs were found, fully in agreement with the effects of these compounds on sirolimus-induced K562 erythroid differentiation (Figures 2 and 3). In Figure 4, relevant examples of the $\mathrm{p}$ values obtained are shown, while the complete statistical analysis is presented in Supplementary Figures S5-S7.

The effects of CincD, QuinD, and CincN were dose-dependent, but clearly evident even when sub-optimal concentrations of compounds were employed.

Among the different combinations studied, those based on cinchonidine and quinidine were found to be the most effective in terms of inducing increases in the proportion of benzidine-positive cells and increased expression of globin genes (Supplementary Figures S5 and S6). Therefore, these two compounds were selected for further studies using erythroid precursor cells (ErPCs) from $\beta$-thalassemia patients as an experimental model system. 

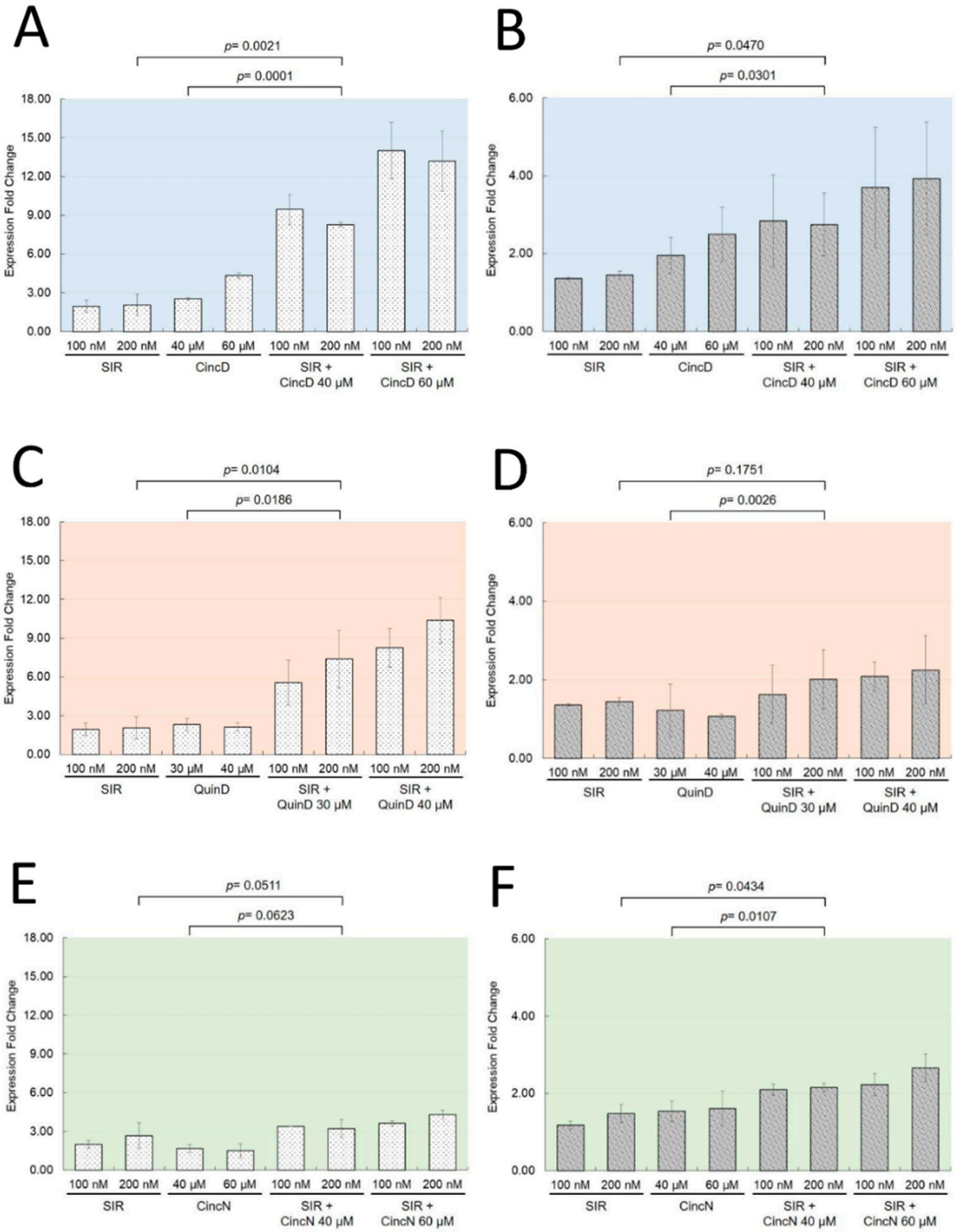

Figure 4. Effects of cinchonidine, quinidine and cinchonine on $\alpha$-globin (left) and $\gamma$-globin (right) mRNAs. K562 cells were cultured with increasing concentrations of $\operatorname{CincD}(\mathbf{A}, \mathbf{B})$, QuinD (C,D) and CincN (E,F) in the presence of $100 \mathrm{nM}$ and $200 \mathrm{nM}$ sirolimus (SIR) as indicated. After 5 days of treatment, RNA was isolated and RT-qPCR was performed using primers amplifying $\alpha$-globin $(\mathbf{A}, \mathbf{C}, \mathbf{E})$ and $\gamma$-globin $(\mathbf{B}, \mathbf{D}, \mathbf{F})$ sequences. The increase in expression of $\alpha$-globin and $\gamma$-globin mRNAs is presented as fold change with respect to control untreated cells. The data represent the average \pm S.E.M. $(n=3)$. 


\subsection{Cinchonidine and Quinidine Induce HbF and $\gamma$-Globin mRNA in Erythroid Precursor Cells} (ErPCs) from $\beta$-Thalassemia Patients

Patients were recruited at the Thalassemia Centre of Azienda Ospedaliera-Universitaria S. Anna (Ferrara, Italy). In total, 10 patients were enrolled. Informed written consent from all participants was obtained before recruiting them into the study. Different genotypes were present in the recruited cohort: five patients were $\beta^{0} 39 / \beta^{+}$IVSI-110, two patients were $\beta^{+}$IVSI-110 $/ \beta^{+}$IVSI-110 and three patients were $\beta^{0} 39 / \beta^{0} 39$. ErPCs were isolated from the $\beta$-thalassemia patients and cultured, as described elsewhere [59], with erythropoietin in the presence of sirolimus, cinchonidine and quinidine administered alone (this was performed in ErPC cultures from all the ten patients) or in combination (this was performed in ErPC cultures from five patients).

In Figure 5, the HPLC profiles of two representative ErPC populations are shown, one isolated from patient \#10 (Figure 5A-C) and the other from patient \#5 (Figure 5D-F), exhibiting a differential response to cinchonidine (Figure 5B,E) and quinidine (Figure 5C,F) treatment.

The ErPCs from patient \#10 exhibited a $69.57 \%$ and $118.04 \%$ increase in $\mathrm{HbF}$ after treatment with cinchonidine and quinidine, respectively (see the raw data shown in Supplementary Table S1). A lower increase in $\mathrm{HbF}$ was obtained when the ErPCs from patient \#1 were employed (in this case, the $\mathrm{HbF}$ increase was $5.40 \%$ and $9.53 \%$ for cinchonidine and quinidine, respectively).
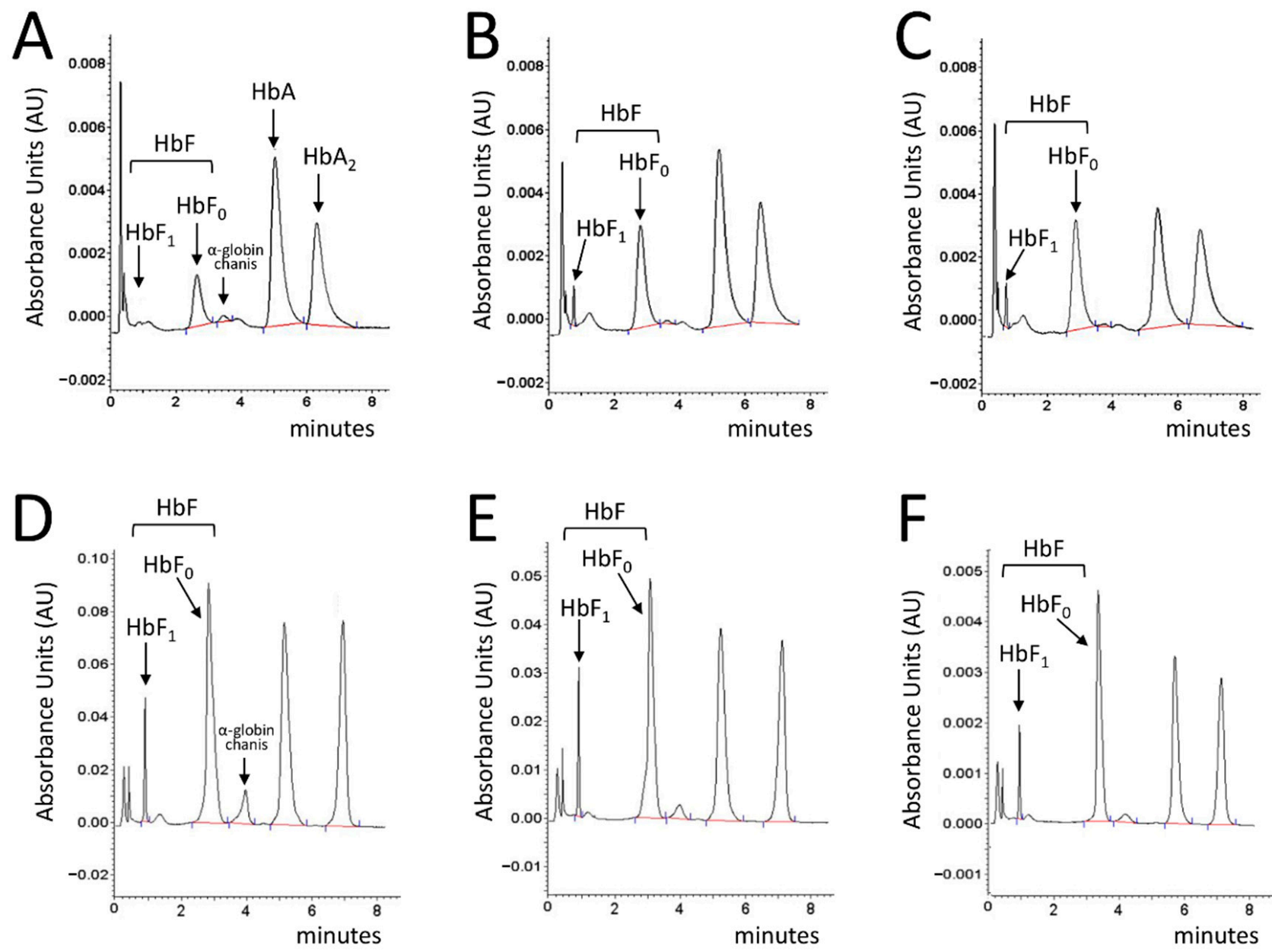

Figure 5. HPLC profile of cytoplasm isolated from ErPCs treated with cinchonidine and quinidine. ErPCs isolated from patient \#10 (A-C) and patient \#1 (D-F) were treated with $60 \mu \mathrm{M}$ cinchonidine (B,E) and $30 \mu \mathrm{M}$ quinidine (C,F) for 7 days and the lysate was analyzed by HPLC. HPLC profiles of untreated ErPCs are depicted in panels (A,D). The peaks corresponding to $\mathrm{HbF}$, free $\alpha$-globin chains, $\mathrm{HbA}$ and $\mathrm{HbA}_{2}$ are shown. 
Figure 6 shows the effects of cinchonidine and quinidine on the ErPCs from all the 10 recruited $\beta$-thalassemia patients. All the raw data are reported in Supplementary Table S1. As clearly evident, increases in the proportion of $\mathrm{HbF}(\%$ of all the accumulated hemoglobins) were found in the treated ErPCs from most of the recruited $\beta$-thalassemia patients (Figure 6A).
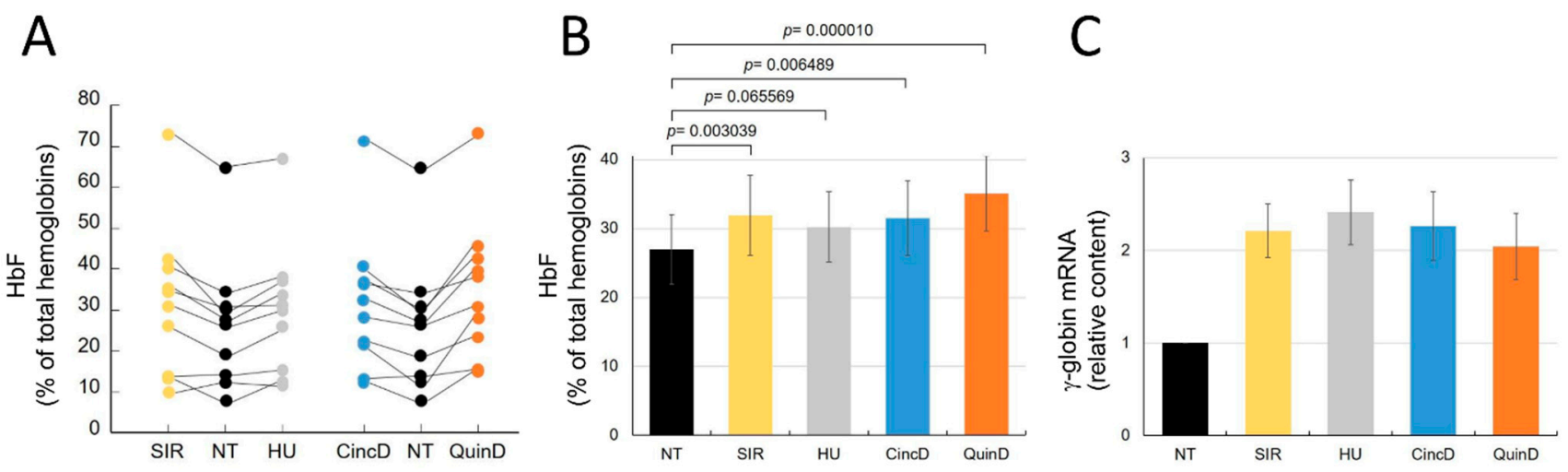

Figure 6. Effects of cinchonidine and quinidine on the HbF production and $\gamma$-globin gene expression in treated ErPCs. ErPcs isolated from $10 \beta$-thalassemia patients were treated with $100 \mathrm{nM}$ sirolimus (SIR), $100 \mu \mathrm{M}$ hydroxyurea (HU), $60 \mu \mathrm{M}$ cinchonidine (CincD) and $30 \mu \mathrm{M}$ quinidine (QuinD) for 7 days. The lysate was analyzed by HPLC for HbF quantification (\% with repect to total $\mathrm{HbF}$ produced) and the RNA was analyzed by RT-qPCR for determination of the relative $\gamma$-globin mRNA content. The raw data of $\mathrm{HbF}$ content are shown in the Supplementary Table S1. The \% of HbF following the different treatments are reported in $(\mathbf{A}, \mathbf{B})$. The increase in $\gamma$-globin mRNA content is shown in (C). The results of panels $(\mathbf{B}, \mathbf{C})$ are reported as mean \pm S.E.M. $(n=10)$.

Figure $6 \mathrm{~B}$ presented this increase in the $\%$ of $\mathrm{HbF}$ with respect to untreated ErPCs and gives evidence for an $\mathrm{HbF}$ increase comparable to that of sirolimus and the established $\mathrm{HbF}$ inducer hydroxyurea.

In fact, the $\mathrm{HbF}$ increase was significant in the treated cells when the obtained values were compared to those found in untreated cells (Figure 6B).

As expected for $\mathrm{HbF}$ inducers, the differences were not statistically significant when the data of CincD- and/or QuinD-treated ErPCs were compared with those obtained using SIR or HU.

The $\mathrm{HbF}$ increase was, as expected, associated with increase in $\gamma$-globin mRNA (Figure 6C). Moreover, in this case, the increases in $\gamma$-globin mRNA $(2.26 \pm 0.37$ and $2.04 \pm 0.36$ folds for cinchonidine and quinidine, respectively) were similar to the increases found in sirolimus-treated $(2.21 \pm 0.29)$ and hydroxyurea-treated $(2.41 \pm 0.35)$ ErPCs. The expected slight inhibitory effects of CincD and QuinD on ErPC cell proliferation were similar to those of the validated $\mathrm{HbF}$ inducers SIR and HU (Supplementary Figure S8).

\subsection{Cinchonidine and Quinidine Potentiate Sirolimus-Mediated Induction of HbF and $\gamma$-Globin} $m R N A$ in ErPCs from $\beta$-Thalassemia Patients

Figure 7 shows the data obtained when ErPCs from five patients were treated, in addition to the treatments already mentioned in Section 2.4, with cinchonidine and quinidine in the presence of $100 \mathrm{nM}$ sirolimus. The data reported are related to increase in the $\%$ of $\mathrm{HbF}$ and of $\gamma$-globin mRNA content. As clearly evident, the ErPC cultures exhibiting the highest levels of $\%$ of $\mathrm{HbF}$ and increased $\gamma$-globin mRNA are those treated with the two alkaloids and sirolimus (the raw data are reported in Supplementary Table S2). For instance, the \% increase in $\mathrm{HbF}$ was $66.30 \pm 25.09$ and $82.30 \pm 37.18$ in ErPCs co-treated with sirolimus plus cinchonidine or sirolimus plus quinidine, respectively. These values were higher than those found when single drugs were added $(20.45 \pm 13.82,31.61 \pm 11.62$ and $54.83 \pm 19.52$ for sirolimus, cinchonidine and quinidine, respectively). When the values relative to the treatments with CincD plus SIR and with QuinD plus SIR were compared to the treatment 
with the reference $\mathrm{HbF}$ inducers $\mathrm{HU}$ and SIR, the differences in the \% of $\mathrm{HbF}$ incresae were found to be highly significant (Figure 7A, upper part of the panel). On the contrary, when the values of CincD or QuinD are compared to HU or SIR, the differences were not significant $(p>0.2)$.

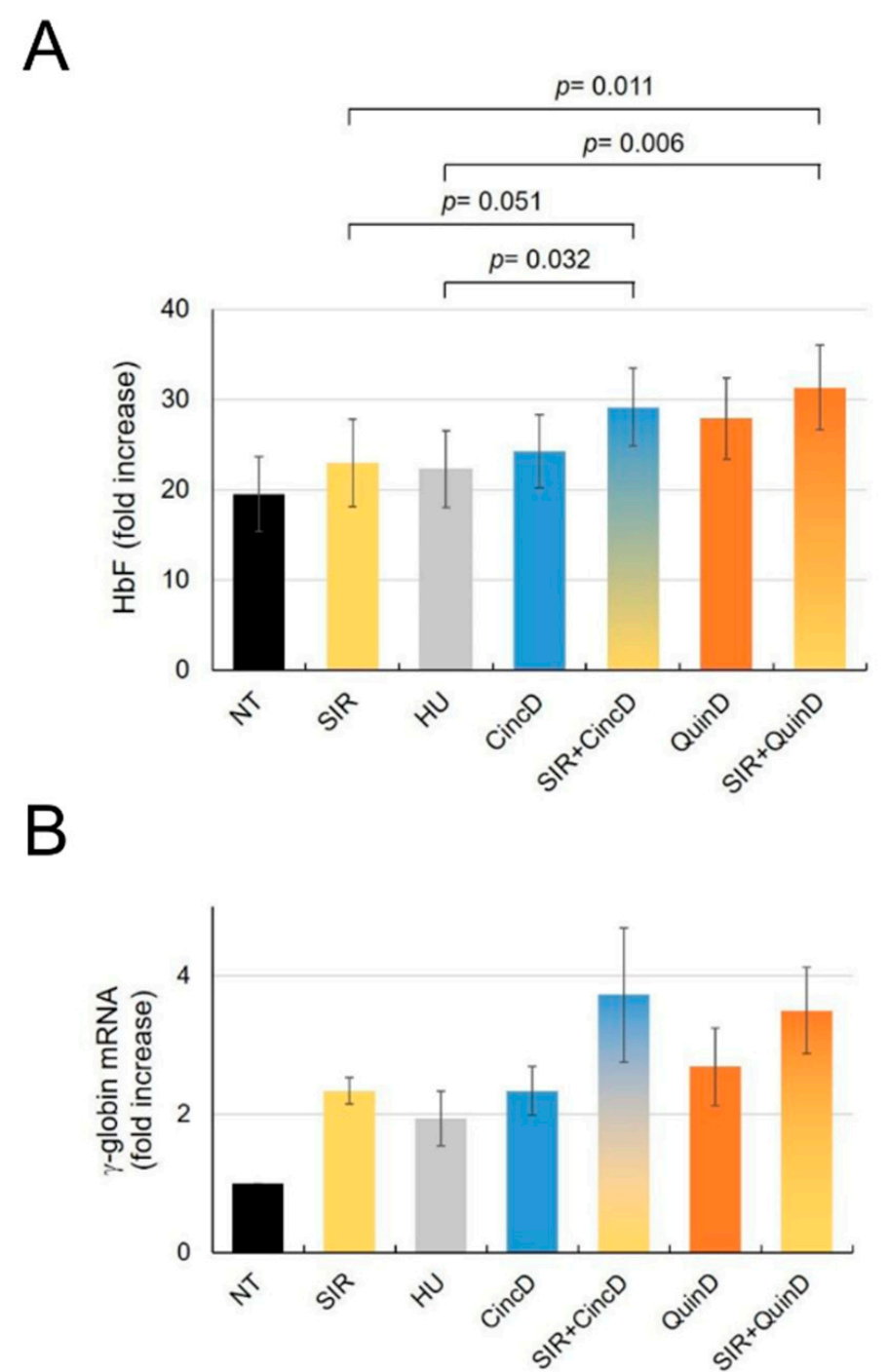

Figure 7. Effects of co-treatment of ErPCs with sirolimus and cinchonidine or quinidine. ErPCs isolated from five $\beta$-thalassemia patients were treated, as indicated, for 7 days with $100 \mathrm{nM}$ sirolimus (SIR), $100 \mu \mathrm{M}$ hydroxyurea (HU), $60 \mu \mathrm{M}$ cinchonidine (CincD), $30 \mu \mathrm{M}$ quinidine (QuinD) or with SIR + CincD or SIR + QuinD. The lysates were analyzed by HPLC for HbF quantification and the RNA by RT-qPCR for determination of the $\gamma$-globin mRNA content. The average increases in $\mathrm{HbF}$ are reported in (A), the increase in $\gamma$-globin mRNA content is shown in $(\mathbf{B})$. The data represent the mean \pm S.E.M. $(n=5)$.

2.6. Treatment of ErPCs from $\beta$-Thalassemia Patients with Cinchonidine and Quinidine Is Associated with a Sharp Decrease in the Free $\alpha$-Globin Chains

Reduction in the excess $\alpha$-globin should be considered as an important objective in the development of therapeutic interventions of $\beta$-thalassemia, since the excess $\alpha$-globin decreases the lifespan of the red-blood cells, causes ineffective erythropoiesis and is a major determinant of the clinical severity of $\beta$-thalassemia [42]. 
The effects of cinchonidine and quinidine on the free $\alpha$-globin chains produced by the ErPCs from the recruited $\beta$-thalassemia patients displaying $\alpha$-globin $>2.5$ are summarized in Figure 8. All the raw data are reported in Supplementary Table S3.

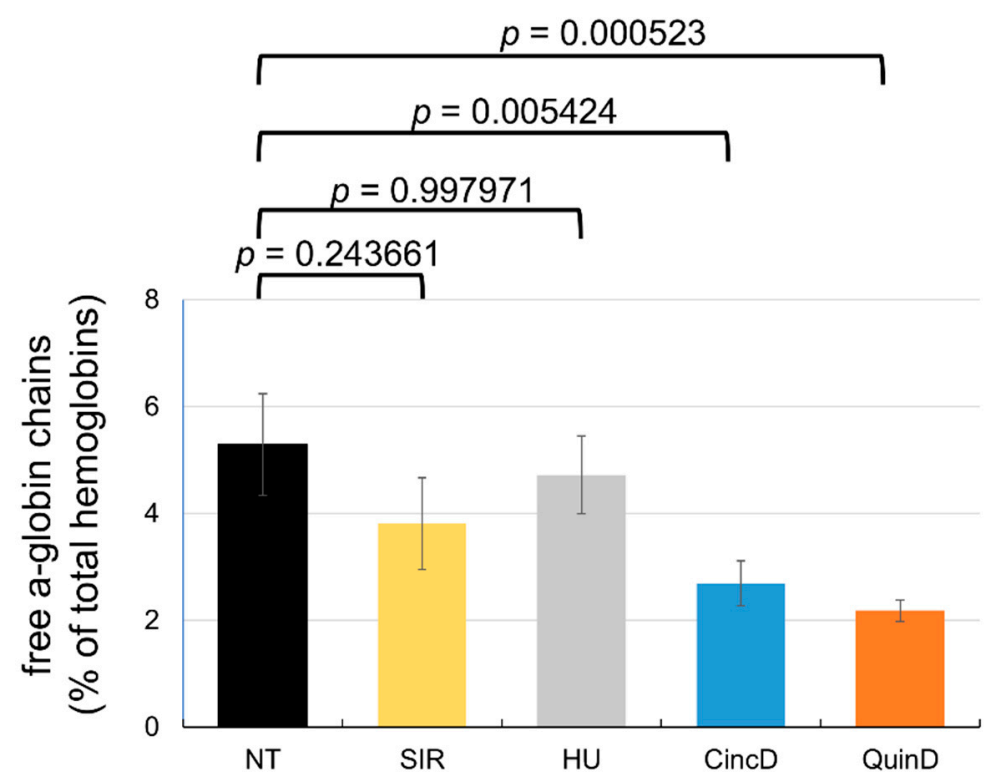

Figure 8. Effects of cinchonidine and quinidine on the free $\alpha$-globin chains. ErPCs isolated from $\beta$-thalassemia patients were treated as indicated for 7 days with $100 \mathrm{nM}$ sirolimus (SIR), $100 \mu \mathrm{M}$ hydroxyurea (HU), $60 \mu \mathrm{M}$ cinchonidine (CincD) and $30 \mu \mathrm{M}$ quinidine (QuinD). The lysates were analyzed by HPLC (see Figure 5 for representative profiles) for quantification of free $\alpha$-globin chains. The data represent the mean \pm S.E.M. $(n=10)$.

As clearly evident, a decrease in the $\%$ of the free $\alpha$-globin peak was found in the treated ErPCs from most of the recruited $\beta$-thalassemia patients (see Supplementary Table S3). Of great interest is a lower reduction in the free $\alpha$-globin chains when ErPCs were treated with sirolimus or hydroxyurea. An average $\alpha$-globin peak reduction of $27.98 \%$ was found with sirolimus, while the $\%$ average reduction with hydroxyurea was only $10.78 \%$. Higher and more significant reductions ( $p=0.024504$ and 0.006129 , respectively) were found with cinchonidine and quinidine $(49.15 \%$ and $58.79 \%$, respectively). These data suggest that, in addition to increased expression of $\gamma$-globin genes and $\mathrm{HbF}$ production, cinchonidine and quinidine might exert their beneficial effects on ErPCs through a decrease in the excess free $\alpha$-globin chains.

\section{Discussion}

Induction of fetal hemoglobin $(\mathrm{HbF})$ is considered a very promising strategy in the therapy of $\beta$-thalassemia and sickle-cell disease (SCD). The gene-therapy-mediated induction of $\gamma$-globin gene expression and HbF production in erythroid cells was described. In addition, approaches using genome editing are available in forms that are finalized to the induction of $\mathrm{HbF}$ following the elimination of genomic sequences encoding for transcriptional repressors or genomic sequences targeted by these regulatory factors [15-19].

While some positive results have been described based on $\mathrm{HbF}$ induction by gene therapy and gene editing, the safety of these approaches are still to be determined. In addition, it is expected that the costs of these therapeutic interventions will be very high [21-23].

Accordingly, the validation of the clinical relevance of already-known $\mathrm{HbF}$ inducers and the characterization of novel $\mathrm{HbF}$ inducers are still projects of great interest [24-27]. In this context, a paper was recently published by Iftikhar et al. on the effects of Cinchona alkaloids (cinchonidine and quinidine) as natural fetal hemoglobin-inducing agents in 
human erythroleukemia cells [28]. This study was very interesting, despite the fact that the key results were obtained using only K562 cells as an in vitro experimental model system.

The key conclusions of our study are the following: (a) cinchonidine and quinidine are inducers of an increase in the $\%$ of $\mathrm{HbF}$ in erythroid progenitor cells isolated from $\beta$-thalassemia patients; (b) cinchonidine and quinidine potentiate the activity of sirolimus (a $\mathrm{HbF}$ inducer employed in clinical trials). These data sustain the concept that cinchonidine and quinidine should be considered for further studies aimed at developing protocols for the treatment of $\beta$-thalassemia patients. Our data show that the $\mathrm{HbF}$ induction efficiency of cinchonidine and quinidine is similar to that of hydroxyurea (the reference $\mathrm{HbF}$ inducer) and sirolimus (Figure 6).

In addition to the induction of changes in $\mathrm{HbF}$ expression, cinchonidine and quinidine might also act through a reduction in the excess free $\alpha$-globins present in the erythroid cells of $\beta$-thalassemia patients. This reduction should be considered a key objective in the use of molecules for therapeutic interventions in the management of $\beta$-thalassemia, since the excess $\alpha$-globin is one of key factors causing short lifespans of the red-blood cells with associated ineffective erythropoiesis [42]. Interestingly, this therapeutic relevant target is reached very efficiently using cinchonidine and quinidine, as both are more efficient in reducing the excess free $\alpha$-globin than hydroxyurea and sirolimus (Figure 8 ). Further studies will clarify whether the reduction in the excess $\alpha$-globin is associated with the activation of autophagy, as proposed elsewhere [42].

In terms of combined treatments, we decided to employ sirolimus [35] as this $\mathrm{HbF}$ inducer is, at present, employed in two ongoing clinical trials: NCT03877809 (A Personalized Medicine Approach for $\beta$-thalassemia Transfusion Dependent Patients: Testing sirolimus in a First Pilot Clinical Trial) and NCT04247750 (Treatment of $\beta$-thalassemia Patients with Rapamycin: From Pre-clinical Research to a Clinical Trial) [45]. Further studies will verify whether the Cinchona alkaloids employed in this study potentiate the activity of other $\mathrm{HbF}$ inducers, including hydroxyurea, that are extensively employed in the treatment of $\beta$-thalassemia and sickle-cell disease [62,63]. One of the limits of our study is that the mechanism(s) of action was not experimentally evaluated. Further studies are required to understand this specific issue in our ErPC model system. However, published studies support the hypothesis that the mechanism(s) of action of Cinchona alkaloids and sirolimus are sharply different. In fact, Cinchona alkaloids are reported to inhibit cytochrome P450 enzyme 2D6 and the transport protein P-glycoprotein [64,65], while sirolimus is firmly established as an mTOR inhibitor $[35,66]$.

The data obtained in our study strongly support the concept that cinchonidine and quinidine might be employed in combination with sirolimus in order to maximize its effects on in vivo-treated $\beta$-thalassemia patients.

In this respect, it is interesting to observe that cinchonidine and quinidine might be more active than hydroxyurea, which is one of the most important reference compounds when clinical treatment of $\beta$-thalassemia and sickle-cell disease is considered [62,63]. Further studies employing analyses of the effects on transcriptome and proteome, as well as confirming the presence of increased $\mathrm{HbF}$ within selected cell populations, are needed in order to verify whether the increase in the $\%$ of $\mathrm{HbF}$ reported in the present study is accompanied by a clinically relevant increase in the content of $\mathrm{HbF}$ in each treated erythroid cell.

Moreover, in order to propose a possible protocol for therapeutic purposes, a proofof-principle showing in vivo effects on animal model systems is highly recommended, as well as a careful analysis of the relationship between the effects on $\mathrm{HbF}$ and the presence of DNA polymorphisms associated with the predisposition of patients to high $\mathrm{HbF}$ induction. 


\section{Materials and Methods}

\subsection{Patients Recruitment}

Cultures of erythroid progenitors were derived from the peripheral blood of $\beta$-thalassemia patients. Patients were recruited at the Day Hospital Thalassemia and Hemoglobinophaties of Azienda Ospedaliera-Universitaria S. Anna (Ferrara, Italy). All the patients received a patient information sheet to read and time to clarify doubts with investigators before consenting. All the participants signed an informed consent form on the basis of approvals of the Ethical Committee in charge of human studies at the University Hospital. The recruited patients were all transfusion dependent and not under hydroxyurea therapy. Treatments were performed on cultured ErPCs derived from patients blood isolated just before transfusion.

\subsection{Chemical Reagents for Cell Culture Treatments}

The reagents used for K562 treatments (rapamycin (sirolimus, SIR), cat. R0395; hydroxyurea (HU), cat. H8627; cinchonine (CincN), cat. 27370; cinchonidine (CincD), cat. C80407; quinidine (QuinD), cat. 22600) were purchased from Sigma Aldrich (St. Louis, MO, USA). $\mathrm{HU}$ was solubilized in sterile deionized $\mathrm{H}_{2} \mathrm{O}$, whereas rapamycin, cinchonine, cinchonidine and quinidine were solubilized in ethanol and stored at $-20^{\circ} \mathrm{C}$. Stock solution of rapamycin was prepared at $5 \mathrm{mM}$ and $20 \mathrm{mM}$ for each of the Cinchona alkaloids used. We used a concentration of sirolimus known to induce both K562 and erythroid precursor cells from $\beta$-thalassemia patients [37]. These stocks were further diluted to the indicated concentrations in culture medium prior to experimentation. All the treatments were performed by adding the compounds once at the beginning of the culturing period.

\subsection{Human K562 Cell Cultures}

The human leukemia K562 [26,36] cells were cultured in a humidified atmosphere of 5\% $\mathrm{CO}_{2}$ /air in RPMI 1640 medium (RPMI 1640 medium; Lonza, Verviers, Belgium) supplemented with $10 \%$ (vol/vol) fetal bovine serum (FBS; Biowest, Nuaille, France) and $1 \%$ penicillin-streptomycin (Euroclone, Milano, Italy). Cell growth was studied by determining the cell number per $\mathrm{ml}$ with a Z2 Coulter Counter (Beckman Coulter, Fullerton, CA, USA).

\subsection{In Vitro Culture of Erythroid Progenitors from $\beta$-Thalassemia Patients}

The two-phase liquid culture procedure was employed as previously described $[37,59]$. Mononuclear cells were isolated from peripheral blood samples of $\beta$-thalassemia patients: 20-25 mL of peripheral blood were collected before transfusion from patients who gave informed consent. A mixture of blood and PBS $1 \times$ at a 1:1 ratio was stratified on top of Lympholyte ${ }^{\circledR}-\mathrm{H}$ Cell Separation Media (Cedarlane, Burlington, NC, USA). After isolation, the mononuclear cell layer was washed three times by adding $1 \times$ PBS solution and seeded in $\alpha$-minimal essential medium ( $\alpha$-MEM; Sigma Aldrich, St. Louis, MO, USA) supplemented with $10 \%$ FBS (FBS; Biowest, Nuaille, France), $1 \mu \mathrm{g} / \mathrm{mL}$ cyclosporine A (Sigma Aldrich, St. Louis, MO, USA), 10\% conditioned medium from the 5637 bladder carcinoma cell line culture and stem cell factor (SCF, Life Technologies, Monza, MB, Italy) at the final concentration of $10 \mathrm{ng} / \mathrm{ml}$. The cultures were incubated at $37^{\circ} \mathrm{C}$, under an atmosphere of $5 \% \mathrm{CO}_{2}$, with extra humidity. After 7 days in this phase-I culture, the non-adherent cells were harvested from the flask, washed in 1x PBS, and then cultured in phase-II medium, composed of $\alpha$-MEM medium (Sigma Aldrich, St. Louis, MO, USA), 30\% FBS (FBS; Biowest, Nuaille, France), $1 \%$ deionized bovine serum albumin (BSA, Sigma Aldrich, St. Louis, MO, USA), $10^{-5} \mathrm{M} \beta$-mercaptoethanol (Sigma Aldrich, St. Louis, MO, USA), $2 \mathrm{mM} \mathrm{L-}$ glutamine (Sigma Aldrich, St. Louis, MO, USA), $10^{-6} \mathrm{M}$ dexamethasone (Dexamethasone 21-phosphate disodium salt; Sigma Aldrich, St. Louis, MO, USA) and $1 \mathrm{U} / \mathrm{mL}$ human recombinant erythropoietin (EPO) (Tebu-bio, Magenta, Milano, Italy) and stem cell factor (SCF) at the final concentration of $10 \mathrm{ng} / \mathrm{mL}$. Erythroid precursor cells' differentiation was assessed by benzidine staining [59]. 


\subsection{Reverse Transcription and Quantitative Real-Time PCR (RT-qPCR)}

For gene expression analysis, $500 \mathrm{ng}$ of total RNA were reverse transcribed using the TaqMan ${ }^{\circledR}$ Reverse Transcription Reagents kit and random hexamers (Applied Biosystems, Foster City, CA, USA). The RT-qPCR assay was carried out using gene-specific double fluorescently labeled probes. The reaction mixture had a final volume of $25 \mu \mathrm{L}$ and was composed of Prime Time ${ }^{\circledR}$ Gene Expression Master Mix $1 \times$ (IDT, Tema Research, Castenaso, $\mathrm{BO}$, Italy), the pairs of forward and reverse primers $(\alpha, \beta, \gamma$, together or GAPDH, RPL13A, $A C T B$ together) used at $500 \mathrm{nM}$ concentration and the probes $(\alpha, \beta, \gamma$, together or GAPDH, RPL13A, ACTB together) used at $250 \mathrm{nM}$ concentration. The probes that contained 6carboxyfluorescein (FAM) and hexachloro-6-carboxyfluorescein (HEX) as chromogenic molecules at $5^{\prime}$ were quenched by the Iowa Black ${ }^{\circledR}$ FQ molecule at $3^{\prime}$, while probes that contained indocarbocyanine (Cy5) were quenched by Iowa Black ${ }^{\circledR}$ RQ. After an initial step for the denaturation at $95^{\circ} \mathrm{C}$ for $2 \mathrm{~min}$, the reactions were performed for 50 cycles consisting of two phases, $95^{\circ} \mathrm{C}$ for $10 \mathrm{~s}$ and $60^{\circ} \mathrm{C}$ for $45 \mathrm{~s}$.

\subsection{HPLC Analysis of Hemoglobins}

To evaluate the effective quantity of the various types of hemoglobin produced by the cultured erythroid cells after treatment, High-Performance Liquid Chromatography was performed. The ErPCs were centrifuged at $2000 \mathrm{rpm}$ for 6 minutes and washed with PBS (Phosphate buffered saline). The pellet was then resuspended in a predefined volume of water for HPLC (Sigma-Aldrich, St. Louis, MO, USA). This was followed by 3 freeze/thaw cycles on dry ice in order to lyse the cells and obtain the protein extracts. Lysates were centrifuged for $5 \mathrm{~min}$ at 14,000 rpm and the supernatant was collected. Hemoglobin analysis was performed by loading the protein extracts into a PolyCAT-A cation exchange column, and they were then eluted in a sodium-chloride-BisTris-KCN aqueous mobile phase using the HPLC Beckman Coulter Instrument System Gold 126 Solvent Module-166 Detector, which allowed us to obtain a quantification of the hemoglobins present in the sample. The reading was performed at a wavelength of $415 \mathrm{~nm}$, and a commercial solution of purified human $\mathrm{HbAF}$ (Sigma-Aldrich) extracts was used as a standard. The values thus obtained were processed using "32 Karat software".

\subsection{Statistical Analysis}

All the data were normally distributed and presented as mean \pm S.E.M. Statistical differences between groups were compared using a paired $t$-test or a one-way repeated measures ANOVA (ANalyses of VAriance between groups) followed by LSD post-hoc tests. Statistical differences were considered significant when $p<0.05\left(^{*}\right)$ and highly significant when $p<0.01(* *)$.

Supplementary Materials: The following are available online at https:/ /www.mdpi.com/article/10 $.3390 / \mathrm{ijms} 222413433 / \mathrm{s} 1$.

Author Contributions: Conceptualization, A.F. and R.G.; methodology, validation, C.Z., L.C.C., M.Z. and I.L.; formal analysis, R.G. and A.F.; investigation, A.F. and C.Z.; lab resources, R.G., I.L. and M.B.; data curation, C.Z. and A.F.; statistical analysis, C.S.; writing—original draft preparation, R.G., C.Z. and A.F.; writing-review and editing, R.G. and A.F.; supervision, R.G. and A.F.; project administration, A.F.; funding acquisition, R.G. and A.F. All authors have read and agreed to the published version of the manuscript.

Funding: This study was sponsored by the Wellcome Trust (Innovator Award 208872/Z/17/Z) and AIFA (AIFA-2016-02364887). The research leading to these results has also received funding by the UE THALAMOSS Project (Thalassemia Modular Stratification System for Personalized Therapy of Beta-Thalassemia; no. 306201-FP7- HEALTH-2012-INNOVATION-1) and FIR and FAR funds from the University of Ferrara. This research was also supported by ALT (Associazione per la lotta alla Talassemia "Rino Vullo"—Ferrara, AVLT (Associazione Veneta per la Lotta alla Talassemia "Elio Zago" - APS), and by the Interuniversity Consortium for Biotechnology (C.I.B.), Italy. C.Z. was supported by a fellowship from "Tutti per Chiara Onlus". 
Institutional Review Board Statement: The study was conducted according to the guidelines of the Declaration of Helsinki and the use of human material was approved by the Ethics Committee of Ferrara's District, protocol name: THAL-THER, document number 533/2018/Sper/AOUFe, approved on 14 November 2018. All samples of peripheral blood were obtained after receiving written informed consent from donor patients or their legal representatives.

Informed Consent Statement: Informed consent for the testing of $\mathrm{HbF}$ inducers in erythroid progenitors derived from peripheral blood was obtained from all $\beta$-thalassemia patients involved in the study before the blood was drawn.

Data Availability Statement: Most of the raw data are included in Supplementary Materials. Additional information will be freely available upon request to the correspondence authors.

Acknowledgments: We thank Marco Prosdocimi (Rare Partners srl) for helpful suggestions. This study is dedicated to the memory of Chiara Gemmo and Elio Zago. The authors wish to thank all $\beta$-thalassemia patients who participated in this study.

Conflicts of Interest: The authors declare no conflict of interest.

\section{Abbreviations}

$\mathrm{Hb}$, hemoglobin; $\mathrm{HbA}$, adult hemoglobin; $\mathrm{HbF}$, fetal hemoglobin; $\mathrm{HPFH}$, hereditary persistence of fetal hemoglobin; SCD, sickle-cell disease; ErPCs, erythroid precursor cells, CincD, cinchonidine, QuinD, quinidine; CincN, cinchonine, SIR, Sirolimus; HU, hydroxyurea; RT-qPCR, Reverse Transcription quantitative real-time PCR; HPLC, High Performance Liquid Chromatography.

\section{References}

1. Weatherall, D.J. Phenotype-genotype relationships in monogenic disease: Lessons from the thalassaemias. Nat. Rev. Genet. 2001, 2, 245-255. [CrossRef]

2. Origa, R. $\beta$-Thalassemia. Genet. Med. 2017, 19, 609-619. [CrossRef] [PubMed]

3. Fucharoen, S.; Weatherall, D.J. Progress Toward the Control and Management of the Thalassemias. Hematol. Oncol. Clin. N. Am. 2016, 30, 359-371. [CrossRef]

4. Modell, B.; Darlison, M.; Birgens, H.; Cario, H.; Faustino, P.; Giordano, P.C.; Gulbis, B.; Hopmeier, P.; Lena-Russo, D.; Romao, L.; et al. Epidemiology of haemoglobin disorders in Europe: An overview. Scand. J. Clin. Lab. Investig. 2007, 67, 39-69. [CrossRef] [PubMed]

5. Galanello, R.; Origa, R. B-thalassemia. Orphanet. J. Rare Dis. 2010, 5, 11. [CrossRef] [PubMed]

6. Thein, S.L. The molecular basis of $\beta$-thalassemia. Cold Spring Harb. Perspect. Med. 2013, 3, a011700.

7. Sripichai, O.; Fucharoen, S. Fetal hemoglobin regulation in $\beta$-thalassemia: Heterogeneity, modifiers and therapeutic approaches. Expert Rev. Hematol. 2016, 9, 1129-1137. [CrossRef]

8. Forget, B.G. Molecular basis of hereditary persistence of fetal hemoglobin. Ann. N. Y. Acad. Sci. 1998, 850, 38-44. [CrossRef]

9. Musallam, K.M.; Sankaran, V.G.; Cappellini, M.D.; Duca, L.; Nathan, D.G.; Taher, A.T. Fetal hemoglobin levels and morbidity in untransfused patients with $\beta$-thalassemia intermedia. Blood 2012, 119, 364-367. [CrossRef]

10. Nuinoon, M.; Makarasara, W.; Mushiroda, T.; Setianingsih, I.; Wahidiyat, P.A.; Sripichai, O.; Kumasaka, N.; Takahashi, A.; Svasti, S.; Munkongdee, T.; et al. A genome-wide association identified the common genetic variants influence disease severity in $\beta 0$-thalassemia/hemoglobin E. Hum. Genet. 2010, 127, 303-314. [CrossRef]

11. Danjou, F.; Anni, F.; Perseu, L.; Satta, S.; Dessì, C.; Lai, M.E.; Fortina, P.; Devoto, M.; Galanello, R. Genetic modifiers of b-thalassemia and clinical severity as assessed by age at first transfusion. Haematologica 2012, 97, 989-993. [CrossRef] [PubMed]

12. Badens, C.; Joly, P.; Agouti, I.; Thuret, I.; Gonnet, K.; Fattoum, S.; Francina, A.; Simeoni, M.C.; Loundou, A.; Pissard, S. Variants in genetic modifiers of $\beta$-thalassemia can help to predict the major or intermedia type of the disease. Haematologica 2011, 96, 1712-1714. [CrossRef] [PubMed]

13. Uda, M.; Galanello, R.; Sanna, S.; Lettre, G.; Sankaran, V.G.; Chen, W.; Usala, G.; Busonero, F.; Maschio, A.; Albai, G.; et al. Genome wide association study shows BCL11A associated with persistent fetal hemoglobin and amelioration of the phenotype of $\beta$-thalassemia. Proc. Natl. Acad. Sci. USA 2008, 105, 1620-1625. [CrossRef] [PubMed]

14. Breveglieri, G.; Bianchi, N.; Cosenza, L.C.; Gamberini, M.R.; Chiavilli, F.; Zuccato, C.; Montagner, G.; Borgatti, M.; Lampronti, I.; Finotti, A.; et al. An Agamma-globin G->A gene polymorphism associated with beta(0)39 thalassemia globin gene and high fetal hemoglobin production. BMC Med. Genet. 2017, 18, 93. [CrossRef]

15. Antoniani, C.; Meneghini, V.; Lattanzi, A.; Felix, T.; Romano, O.; Magrin, E.; Weber, L.; Pavani, G.; El Hoss, S.; Kurita, R.; et al. Induction of fetal hemoglobin synthesis by CRISPR/Cas9-mediated editing of the human $\beta$-globin locus. Blood 2018, 131, 1960-1973. [CrossRef] 
16. Wu, Y.; Zeng, J.; Roscoe, B.P.; Liu, P.; Yao, Q.; Lazzarotto, C.R.; Clement, K.; Cole, M.A.; Luk, K.; Baricordi, C.; et al. Highly efficient therapeutic gene editing of human hematopoietic stem cells. Nat. Med. 2019, 25, 776-783. [CrossRef]

17. Métais, J.Y.; Doerfler, P.A.; Mayuranathan, T.; Bauer, D.E.; Fowler, S.C.; Hsieh, M.M.; Katta, V.; Keriwala, S.; Lazzarotto, C.R.; Luk, K.; et al. Genome editing of HBG1 and HBG2 to induce fetal hemoglobin. Blood Adv. 2019, 3, 3379-3392. [CrossRef]

18. Mingoia, M.; Caria, C.A.; Ye, L.; Asunis, I.; Marongiu, M.F.; Manunza, L.; Sollaino, M.C.; Wang, J.; Cabriolu, A.; Kurita, R.; et al. Induction of therapeutic levels of $\mathrm{HbF}$ in genome-edited primary $\beta(0)$ 39-thalassaemia haematopoietic stem and progenitor cells. Br. J. Haematol. 2021, 192, 395-404. [CrossRef]

19. Frangou, H.; Altshuler, D.; Cappellini, M.D.; Chen, Y.S.; Domm, J.; Eustace, B.K.; Foell, J.; de la Fuente, J.; Grupp, S.; Handgretinger, R.; et al. CRISPR-Cas9 Gene Editing for Sickle Cell Disease and $\beta$-Thalassemia. N. Engl. J. Med. 2021, 384, 252-260. [CrossRef]

20. NCT03655678 (A Safety and Efficacy Study Evaluating CTX001 in Subjects with Transfusion-Dependent $\beta$-Thalassemia). Available online: https: / / linicaltrials.gov / ct2/show / NCT03655678 (accessed on 28 November 2021).

21. Sherkow, J.S. CRISPR, Patents, and the Public Health. Yale J. Biol. Med. 2017, 90, 667-672.

22. Rigter, T.; Klein, D.; Weinreich, S.S.; Cornel, M.C. Moving somatic gene editing to the clinic: Routes to market access and reimbursement in Europe. Eur. J. Hum. Genet. 2021, 29, 1477-1484. [CrossRef]

23. Cornel, M.C.; Howard, H.C.; Lim, D.; Bonham, V.L.; Wartiovaara, K. Moving towards a cure in genetics: What is needed to bring somatic gene therapy to the clinic? Eur. J. Hum. Genet. 2019, 27, 484-487. [CrossRef]

24. Finotti, A.; Gambari, R. Recent trends for novel options in experimental biological therapy of $\beta$-thalassemia. Expert Opin. Biol. Ther. 2014, 14, 1443-1454. [CrossRef]

25. Mukherjee, M.; Rahaman, M.; Ray, S.K.; Shukla, P.C.; Dolai, T.K.; Chakravorty, N. Revisiting fetal hemoglobin inducers in beta-hemoglobinopathies: A review of natural products, conventional and combinatorial therapies. Mol. Biol. Rep. 2021. Online ahead of print.

26. Lampronti, I.; Bianchi, N.; Zuccato, C.; Dall'Acqua, F.; Vedaldi, D.; Viola, G.; Potenza, R.; Chiavilli, F.; Breveglieri, G.; Borgatti, M.; et al. Increase in gamma-globin mRNA content in human erythroid cells treated with angelicin analogs. Int. J. Hematol. 2009, 90, 318-327. [CrossRef]

27. Finotti, A.; Bianchi, N.; Fabbri, E.; Borgatti, M.; Breveglieri, G.; Gasparello, J.; Gambari, R. Erythroid induction of K562 cells treated with mithramycin is associated with inhibition of raptor gene transcription and mammalian target of rapamycin complex 1 (mTORC1) functions. Pharmacol. Res. 2015, 91, 57-68. [CrossRef] [PubMed]

28. Iftikhar, F.; Ali, H.; Musharraf, S.G. Cinchona alkaloids as natural fetal hemoglobin inducing agents in human erythroleukemia cells. RSC Adv. 2019, 9, 17551. [CrossRef]

29. Warhurst, D.C. Cinchona alkaloids and malaria. Lancet 1981, 2, 1346.

30. Uzor, P.F. Alkaloids from Plants with Antimalarial Activity: A Review of Recent Studies. Evid. Based Complement. Alternat. Med. 2020, 2020, 8749083. [CrossRef] [PubMed]

31. Maldonado, C.; Barnes, C.J.; Cornett, C.; Holmfred, E.; Hansen, S.H.; Persson, C.; Antonelli, A.; Rønsted, N. Phylogeny Predicts the Quantity of Antimalarial Alkaloids within the Iconic Yellow Cinchona Bark (Rubiaceae: Cinchona calisaya). Front. Plant. Sci. 2017, 8, 391. [CrossRef]

32. Deshmukh, A.; Larson, J.; Ghannam, M.; Saeed, M.; Cunnane, R.; Ghanbari, H.; Latchamsetty, R.; Crawford, T.; Jongnarangsin, K.; Pelosi, F.; et al. Efficacy and tolerability of quinidine as salvage therapy for monomorphic ventricular tachycardia in patients with structural heart disease. J. Cardiovasc. Electrophysiol. 2021. Online ahead of print.

33. Vitali Serdoz, L.; Rittger, H.; Furlanello, F.; Bastian, D. Quinidine-A legacy within the modern era of antiarrhythmic therapy. Pharmacol. Res. 2019, 144, 257-263. [CrossRef] [PubMed]

34. Li, D.L.; Cox, Z.L.; Richardson, T.D.; Kanagasundram, A.N.; Saavedra, P.J.; Shen, S.T.; Montgomery, J.A.; Murray, K.T.; Roden, D.M.; Stevenson, W.G. Quinidine in the Management of Recurrent Ventricular Arrhythmias: A Reappraisal. JACC Clin. Electrophysiol. 2021, 7, 1254-1263. [CrossRef]

35. Sehgal, S.N. Sirolimus: Its discovery, biological properties, and mechanism of action. Transplant. Proc. 2003, 35, 7S-14S. [CrossRef]

36. Mischiati, C.; Sereni, A.; Lampronti, I.; Bianchi, N.; Borgatti, M.; Prus, E.; Fibach, E.; Gambari, R. Rapamycin-mediated induction of gamma-globin mRNA accumulation in human erythroid cells. Br. J. Haematol. 2004, 126, 612-621. [CrossRef] [PubMed]

37. Fibach, E.; Bianchi, N.; Borgatti, M.; Zuccato, C.; Finotti, A.; Lampronti, I.; Prus, E.; Mischiati, C.; Gambari, R. Effects of rapamycin on accumulation of alpha-, $\beta$ - and gamma-globin mRNAs in erythroid precursor cells from $\beta$-thalassaemia patients. Eur. J. Haematol. 2006, 77, 437-441. [CrossRef] [PubMed]

38. Zuccato, C.; Bianchi, N.; Borgatti, M.; Lampronti, I.; Massei, F.; Favre, C.; Gambari, R. Everolimus is a potent inducer of erythroid differentiation and gamma-globin gene expression in human erythroid cells. Acta Haematol. 2007, 117, 168-176. [CrossRef]

39. Pecoraro, A.; Troia, A.; Calzolari, R.; Scazzone, C.; Rigano, P.; Martorana, A.; Sacco, M.; Maggio, A.; Di Marzo, R. Efficacy of Rapamycin as Inducer of $\mathrm{Hb} \mathrm{F}$ in Primary Erythroid Cultures from Sickle Cell Disease and $\beta$-Thalassemia Patients. Hemoglobin 2015, 39, 225-229. [CrossRef]

40. Khaibullina, A.; Almeida, L.E.; Wang, L.; Kamimura, S.; Wong, E.C.; Nouraie, M.; Maric, I.; Albani, S.; Finkel, J.; Quezado, Z.M. Rapamycin increases fetal hemoglobin and ameliorates the nociception phenotype in sickle cell mice. Blood Cells Mol. Dis. 2015, 55, 363-372. [CrossRef]

41. Wang, J.; Tran, J.; Wang, H.; Guo, C.; Harro, D.; Campbell, A.D.; Eitzman, D.T. mTOR Inhibition improves anaemia and reduces organ damage in a murine model of sickle cell disease. Br. J. Haematol. 2016, 174, 461-469. [CrossRef] 
42. Lechauve, C.; Keith, J.; Khandros, E.; Fowler, S.; Mayberry, K.; Freiwan, A.; Thom, C.S.; Delbini, P.; Romero, E.B.; Zhang, J.; et al. The autophagy-activating kinase ULK1 mediates clearance of free $\alpha$-globin in $\beta$-thalassemia. Sci. Transl. Med. 2019, 11 , eaav4881. [CrossRef]

43. Gaudre, N.; Cougoul, P.; Bartolucci, P.; Dörr, G.; Bura-Riviere, A.; Kamar, N.; Del Bello, A. Improved Fetal Hemoglobin With mTOR Inhibitor-Based Immunosuppression in a Kidney Transplant Recipient with Sickle Cell Disease. Am. J. Transplant. 2017, 17, 2212-2214. [CrossRef]

44. Al-Khatti, A.A.; Alkhunaizi, A.M. Additive effect of sirolimus and hydroxycarbamide on fetal haemoglobin level in kidney transplant patients with sickle cell disease. Br. J. Haematol. 2019, 185, 959-961. [CrossRef]

45. Gamberini, M.R.; Prosdocimi, M.; Gambari, R. Sirolimus for Treatment of $\beta$-Thalassemia: From Pre-Clinical Studies to the Design of Clinical Trials. Health Educ. Public Health 2021, 4, 425-435.

46. Kahan, B.D. Sirolimus: A new agent for clinical renal transplantation. Transplant. Proc. 1997, 29, 48-50. [CrossRef]

47. Vasquez, E.M. Sirolimus: A new agent for prevention of renal allograft rejection. Am. J. Health Syst. Pharm. 2000, 57, 437-448. [CrossRef]

48. Schaffer, S.A.; Ross, H.J. Everolimus: Efficacy and safety in cardiac transplantation. Expert Opin. Drug Saf. 2010, 9, 843-854. [CrossRef]

49. Tang, C.Y.; Shen, A.; Wei, X.F.; Li, Q.D.; Liu, R.; Deng, H.J.; Wu, Y.Z.; Wu, Z.J. Everolimus in de novo liver transplant recipients: A systematic review. Hepatobiliary Pancreat. Dis. Int. 2015, 14, 461-469. [CrossRef]

50. Ji, L.; Xie, W.; Zhang, Z. Efficacy and safety of sirolimus in patients with systemic lupus erythematosus: A systematic review and meta-analysis. Semin. Arthritis Rheum. 2020, 50, 1073-1080. [CrossRef]

51. Wang, Q.; Luo, M.; Xiang, B.; Chen, S.; Ji, Y. The efficacy and safety of pharmacological treatments for lymphangioleiomyomatosis. Respir. Res. 2020, 21, 55. [CrossRef]

52. Sasongko, T.H.; Ismail, N.F.; Zabidi-Hussin, Z. Rapamycin and rapalogs for tuberous sclerosis complex. Cochrane Database Syst. Rev. 2016, 7, CD011272. [CrossRef] [PubMed]

53. Graillon, T.; Sanson, M.; Campello, C.; Idbaih, A.; Peyre, M.; Peyrière, H.; Basset, N.; Autran, D.; Roche, C.; Kalamarides, M.; et al. Everolimus and Octreotide for Patients with Recurrent Meningioma: Results from the Phase II CEVOREM Trial. Clin. Cancer Res. 2020, 26, 552-557. [CrossRef]

54. Gallo, M.; Malandrino, P.; Fanciulli, G.; Rota, F.; Faggiano, A.; Colao, A.; NIKE Group. Everolimus as first line therapy for pancreatic neuroendocrine tumours: Current knowledge and future perspectives. J. Cancer Res. Clin. Oncol. 2017, 143, 1209-1224. [CrossRef]

55. Motzer, R.J.; Escudier, B.; Oudard, S.; Hutson, T.E.; Porta, C.; Bracarda, S.; Grünwald, V.; Thompson, J.A.; Figlin, R.A.; Hollaender, N.; et al. Phase 3 trial of everolimus for metastatic renal cell carcinoma: Final results and analysis of prognostic factors. Cancer 2010, 116, 4256-4265. [CrossRef] [PubMed]

56. Algiraigri, A.H.; Wright, N.A.M.; Paolucci, E.O.; Kassam, A. Hydroxyurea for lifelong transfusion-dependent $\beta$-thalassemia: A meta-analysis. Pediatr. Hematol. Oncol. 2017, 34, 435-448. [CrossRef] [PubMed]

57. Bianchi, N.; Finotti, A.; Ferracin, M.; Lampronti, I.; Zuccato, C.; Breveglieri, G.; Brognara, E.; Fabbri, E.; Borgatti, M.; Negrini, M.; et al. Increase of microRNA-210, decrease of raptor gene expression and alteration of mammalian target of rapamycin regulated proteins following mithramycin treatment of human erythroid cells. PLoS ONE 2015, 10, e0121567. [CrossRef]

58. Bianchi, N.; Ongaro, F.; Chiarabelli, C.; Gualandi, L.; Mischiati, C.; Bergamini, P.; Gambari, R. Induction of erythroid differentiation of human K562 cells by cisplatin analogs. Biochem. Pharmacol. 2000, 60, 31-40. [CrossRef]

59. Cosenza, L.C.; Breda, L.; Breveglieri, G.; Zuccato, C.; Finotti, A.; Lampronti, I.; Borgatti, M.; Chiavilli, F.; Gamberini, M.R.; Satta, S.; et al. A validated cellular biobank for $\beta$-thalassemia. J. Transl. Med. 2016, 14, 255. [CrossRef] [PubMed]

60. Gambari, R.; Fibach, E. Medicinal chemistry of fetal hemoglobin inducers for treatment of beta-thalassemia. Curr. Med. Chem. 2007, 14, 199-212. [CrossRef]

61. Bianchi, N.; Chiarabelli, C.; Zuccato, C.; Lampronti, I.; Borgatti, M.; Amari, G.; Delcanale, M.; Chiavilli, F.; Prus, E.; Fibach, E.; et al. Erythroid differentiation ability of butyric acid analogues: Identification of basal chemical structures of new inducers of foetal haemoglobin. Eur. J. Pharmacol. 2015, 752, 84-91. [CrossRef] [PubMed]

62. Hashemi, Z.; Ebrahimzadeh, M.A. Hemoglobin F (HbF) inducers; History, Structure and Efficacies. Mini Rev. Med. Chem. 2021. Online ahead of print.

63. Ansari, S.H.; Lassi, Z.S.; Khowaja, S.M.; Adil, S.O.; Shamsi, T.S. Hydroxyurea (hydroxycarbamide) for transfusion-dependent beta-thalassaemia. Cochrane Database Syst. Rev. 2019, 3, CD012064.

64. McLaughlin, L.A.; Paine, M.J.; Kemp, C.A.; Maréchal, J.D.; Flanagan, J.U.; Ward, C.J.; Sutcliffe, M.J.; Roberts, G.C.; Wolf, C.R. Why is quinidine an inhibitor of cytochrome P450 2D6? The role of key active-site residues in quinidine binding. J. Biol. Chem. 2005, 280, 38617-38624. [CrossRef]

65. Fromm, M.F.; Kim, R.B.; Stein, C.M.; Wilkinson, G.R.; Roden, D.M. Inhibition of P-glycoprotein-mediated drug transport: A unifying mechanism to explain the interaction between digoxin and quinidine [see comments]. Circulation 1999, 99, 552-557. [CrossRef] [PubMed]

66. Ballou, L.M.; Lin, R.Z. Rapamycin and mTOR kinase inhibitors. J. Chem. Biol. 2008, 1, 27-36. [CrossRef] [PubMed] 